\title{
THE DEVELOPMENT OF A CULTURE OF CHILDREN'S BEHAVIOUR IN PRESCHOOL EDUCATION INSTITUTIONS: ANALYSIS OF PRESCHOOL TEACHERS' EXPERIENCE
}

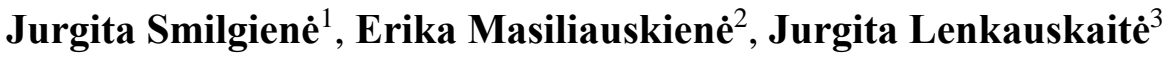

\begin{abstract}
The Lithuanian society lives in the period of changes in which personal values are influenced by our surroundings. The decline of a culture of behaviour is observed in society and it is increasingly evident in children's and youth's behaviour. Children lose their autonomy, respect for the individual and nation. There is increasingly visible rude communication, social environmental intolerance and this just proves that our younger generation has little culture of behaviour. The earlier you introduce children to the basic conduct of cultural values and their aspirations to develop, the better results will be achieved in the correct behaviour modelling for life in society. For this reason, not only the family, but also preschool, i.e., educators, are responsible for the cultured behaviour of children, education and promotion to be polite, respectful, honest, friendly, etc.

The object of the research - the development of a culture of behaviour of preschool age children. The aim - to reveal how a culture of children's behaviour is developed in preschool.

A study was conducted in preschool institutions of Northern Lithuania. In this case a qualitative research strategy was chosen. The methods of the research: analysis and synthesis of the sources of scientific literature and open-ended written survey of preschool educators. Teachers from 23 preschool institutions participated in the research. Qualitative research data were processed using the method of content analysis. The research revealed what concept the respondents give to the definition of a culture of children's behaviour and what methods they apply in their daily work. The concept of a culture of behaviour from the point of view of teachers is: culture of activity, of communication, of hygiene and nurturing nature. Preschool educators develop a culture of behaviour using traditional methods such as games, conversations, reading, literary and cartoon analysis in their professional activities.
\end{abstract}

UDC Classification: 37.04, DOI: https://doi.org/10.12955/pss.v1.73

Keywords: education, children, behavior, culture, preschool, institutions.

\section{Introduction}

In all epochs, the issues of interrelationships and a culture of behaviour were relevant. They remain so in the current times of changes and reforms because each period has the forms of courtesy and attentiveness appropriate only to it, which are suitable for the education of children or adapted to their strengths (Cramm, 2005). The $21^{\text {st }}$ century is a period of change that requires the rapid adjustment of society. However, the traditionally established standards of virtuous behaviour are less and less remembered today, therefore, a lack of a culture of behaviour among members of society is noticeable.

It becomes a normal phenomenon in society to see the examples of inappropriate behaviour among adults and children in public. Attention is increasingly drawn to people's behaviour towards those around them that is getting more and more aggressive. Children's discipline, courtesy, and communication with each other and with adults are getting poorer. This is reflected in the data provided by the Child Line Annual Activity Report 2018 that the most frequently asked questions for the Child Line are related to difficulties in communicating with peers (even 5732 cases) or to bullying experienced (even 3291 cases) (Report Line Annual Activity Report, 2018).

It is surprising that the behaviour of children and young people and their disrespect for adults is becoming a normal phenomenon. It is becoming natural for everyone to see a child in public who is experiencing anger attacks or is out of control. In order to implement the programmes for the development of a culture of behaviour, more attention should be paid to the junior school age children. It is therefore very important for society to get concerned about the development of a culture of children's behaviour at the earliest possible age because at this age, children spend more time with their parents or in educational institutions with other children of that age. According to Burvyte (2016), in many cases children's inappropriate behaviour becomes a concern only when they face difficulties or behavioural problems that are already entrenched and difficult to correct. Improperly educating children in receptive periods of child development, when a personality lifestyle and behavioural patterns are formed, we allow them to acquire inappropriate behavioural skills, which subsequently make it difficult for children and those around them to adapt in society (Weiss, Goebel, Page, et al., 1999). The earlier we introduce children to the core values of a culture of behaviour and seek to develop them, the better

\footnotetext{
${ }^{1}$ Šiauliai University, Institute of Education, Šiauliai, Lithuania, jurgita.smilgiene@gmail.com

2 Šiauliai University, Institute of Education, Šiauliai, Lithuania, erika.masiliauskiene@su.lt

${ }^{3}$ Šiauliai University, Institute of Education, Šiauliai, Lithuania, jurgita.lenkauskaite@ su.lt
} 
results we will have in shaping their appropriate behaviour. For this reason, not only the family but also the preschool is responsible for the development of a culture of children's behaviour, for educating and encouraging children to behave politely, respectfully, honestly, in a friendly manner, etc. (Jung, Reifel, 2011).

Preschool, educators, group - the whole educational environment - are very significant fields of the child's experience, because the kindergarten for the child is a subculture structure, where through social learning processes the child finds out, learns, and assimilates values, attitudes, styles of behaviour and a certain order, and integrates them into his/her personality (Žygaitienè, 2003; Han, 2014).

Developing an appropriate culture of behaviour, adults, who spend every day with the child and with their behaviour and attitude towards them have the greatest influence, are important (Leliūgienè, 2003; Lenartavičienè, 2011). The foundations properly laid in preschool education can lay the foundations of critical thinking for the emerging personality to promote creativity and the quality of relationships with others. In order to achieve the goals, it is necessary to choose the appropriate age and educational methods to achieve positive results.

Many Lithuanian and foreign educators, psychologists and other scientists deal with the issues of a culture of children's behaviour: Bitinas (2004), Cramm (2005), Skujienè and Steponienènè (2007), Jung, Reifel (2011), Jovaiša (2012), Petrylienė, Smilgienè (2013), Masiliauskienė, et al. (2014), Grace (2017), Smilgiené, Jonaitienè (2019). and Žygaitienè (2003) state that the formation of skills and habits of cultured behaviour, versatile application of work techniques, free and unrestricted creative work enable the learners to get to know themselves, create, and express themselves. During the work process, they develop their communication and collaboration skills and responsibility for the results of their own and group performance. Nevertheless, there is a lack of research on the concepts and responsibilities of teachers in developing a culture of behaviour of preschool children.

The object of the research - the development of a culture of behaviour of preschool age children.

The aim - to reveal how a culture of children's behaviour is developed in preschool.

The methods of the research: analysis and synthesis of the sources of scientific literature; conducting a written survey of teachers, twenty-three teachers' experiences about the techniques they apply to develop a culture of children's behaviour were revealed; qualitative research data were processed using the method of content analysis.

\section{Theoretical contextualization of the development of a culture of children's behaviour in a preschool education institution}

In the Law on Education of the Republic of Lithuania (2011), one of the goals of education is "to develop value orientations for each person, which enable him/her to become a virtuous, knowledge-seeking, independent, responsible, patriotic person, to develop his/her communication skills relevant to today's life, to help assimilate the information culture inherent in the knowledge society, $<\ldots>$, as well as modern social competence and the abilities to build one's own life and lead a healthy life". Thus, every educational institution must develop the personality holistically, i.e., to develop values recognized in society, abilities to make decisions independently, and communication skills. The term "culture of behaviour" is used to describe these educational aspects. The scientists Peterina, (1989), Žemaitis, (2005) Alijošienè, (2003;) and Jovaiša, (2012) state that the term "culture of children's behaviour" encompasses the development of both societal and personal values.

Alijošienè (2003) states that the goals of a culture of behaviour can be analysed as an integral part of moral education and formulated as specific requirements: "to develop appropriate hygiene skills, a culture of behaviour in different situations and positive interrelationships in all areas of activity; to develop certain elements of moral consciousness and moral feelings, to form the basics of work education" (p. 13). Žemaitis (2005) considered a culture of behaviour as a whole of human behavioural forms based on morality and aesthetic taste, related to customs and traditions. A culture of behaviour covers a wide range of human interrelationships. According to Peterina (1989), a culture of behaviour is the totality of forms that are useful in society, constant in everyday life, in communication, functioning in various ways. Consequently, a culture of behaviour is an inseparable part of general culture, human education or aesthetic education. As Žemaitis (2005) states, people have always striven for the good, for the order of life, for harmony, and this has led to the emergence of customs and habits of cultured behaviour, which over time have begun to take on the meaning of a culture of behaviour. According to 
Žygaitienè (2003), the knowledge of a culture of behaviour helps us to understand the world, to orientate in different situations, to choose objective criteria for their evaluation, to predict positive behaviour and its consequences.

In the Law on Education of the Republic of Lithuania (2011) it is regulated that the purpose of preschool education is to help the child to meet natural, cultural, as well as ethnic, social and cognitive needs. Preschool is a community, where the child engages in intense social relationships with different adults and peers. It is the preschool that is the first school for the child, where he/she communicates with his/her peers, imitates them, trains, and learns order. Social education is also a very important part of preschool education, as it covers not only the curriculum but also the life of the kindergarten group: the relationships among the group members, the environment, the organization of the educational process, and the behaviour.

Referring to the aforementioned theoretical insights, it can be stated that the development of a culture of children's behaviour is an integral part of social education. As a consequence, the development of a culture of children's behaviour includes the ability to understand oneself and others, one's place in the family, in a group of children, relations with the community, social and cultural phenomena, homeland, native country; ability to be together with others, to communicate, to cooperate, to make friends, to solve everyday problems, to overcome the difficulties of life, to help oneself and others, to feel better and respect oneself, to develop a sense of national identity.

In summary, it is possible to state that a culture of behaviour is a part of a culture of humanity. It focuses on following the most important common rules of life, being able to adequately communicate with people, being helpful, courteous and tactful. The development of a culture of children's behaviour is important because it contributes to the development of basic moral qualities: honesty, discipline, orderliness, independence, obedience, diligence. In this context, the preschool education institution, which aims at comprehensive education of the child, as well as the development of a culture of behaviour, also plays a significant role. Special attention is paid to the development of the child's autonomy, communication and cooperation, courtesy, respect, etiquette, personal hygiene skills.

\section{Methods and organization of the research}

The research was conducted in the preschool institutions of the country. Empirical research was conducted in 23 preschool education institutions in the region of Northern Lithuania. The research includes those educational institutions that have developed and are implementing child value education programmes. The research involved 23 informants (all women with an average age of 47 years), one from each preschool education institution. The research sample was formed by combining two sampling methods: criterion sampling (region - educational institution that implements a value education programme, teacher's professional qualification - methodologist) and random target sampling (if more than one teacher methodologist was working in the institution, one research participant was randomly selected). None of the research participants invited to participate in the research refused to participate. During the survey, the teachers were asked 3 questions: how they identify the concept and content of a culture of behaviour; what techniques and methods of the development of a culture of children's behaviour they apply in their pedagogical work and why; what the most effective methods of the development of a culture of children's behaviour are and why. The interview questions were sent to the teachers by e-mail. The questions were answered in writing.

A qualitative research strategy - systematic investigation of a situation, event, case, individual or group in the natural environment in order to understand the phenomena under investigation and to provide an interpretative explanation derived from the analysis of situations - was chosen to achieve the goal (Bitinas et al., 2008). The method of an open-ended written survey was chosen for data collection (the research took place in September-November, 2019), by asking open-ended questions. The questions helped to reveal the opinion of the teachers about the importance of a culture of behaviour in preschool and the development of a culture of children's behaviour through everyday activities.

The obtained data were processed by the method of content analysis. According to Bitinas et al. (2008), qualitative content analysis is a qualitative diagnostic tool, when the descriptions of the informants' responses are read many times distinguishing essential categories, the content of which may be divided distinguishing the main elements into subcategories and later interpreting the data. The research is based on the theory of social constructivism (Berger and Luckmann, 1966) emphasizing the intersubjective 
component of the construction of meanings. It is revealed when teachers reflect on the situations of everyday life, which provide the opportunities of the development of a culture of children's behaviour that is favourable to the expression of social interaction.

In conducting the research, research ethics was ensured in compliance with the research principles of voluntary participation, benevolence, and justice. Kardelis (2017) points out that respondents have the right to independently decide on their voluntary participation in the research. In preparation for the survey, the teachers were informed that the data would only be used for research purposes, explained how long the questionnaire might take and the right to privacy/confidentiality was guaranteed (the questionnaires were anonymous). Twenty-three preschool teachers agreed to participate in the survey and share their experiences.

In data analysis, the number of participants is indicated by the letter $(\mathrm{N})$. The toolkit - a coding form containing the details of the respondent - was prepared for the analysis of the content of the questionnaire of the preschool teachers. In the coding form, the respondent's questionnaire is coded (1). The mark - 1 - indicates the number of the questionnaire from the total list of the teachers, who participated in the research. A classical (quantitative) analysis of the data of the teachers' survey was performed. Its essence is the calculation of separate textual notional units, exploration of the relationship between different textual elements, both with each other and with the entire volume of information. The text component unit that is evaluated as absolute frequency is distinguished.

\section{Analysis of the research results}

The teachers answering the question how they understand a culture of behaviour provided various options that correspond to the concept of a culture of behaviour. According to Žemaitis (2005), a culture of behaviour is a whole of human behavioural forms based on morality and aesthetic taste, related to customs and traditions. A culture of behaviour covers a wide range of human interrelationships. It is inseparable from general culture and education, aesthetic education. This is exactly what can be seen in the answers provided by the teachers (see Table 1).

\begin{tabular}{|c|c|c|c|}
\hline Category & Subcategory & $\begin{array}{l}\text { The number } \\
\text { of the state }\end{array}$ & $\begin{array}{c}\text { Examples of statements illustrating the } \\
\text { category/subcategory }\end{array}$ \\
\hline \multirow[b]{2}{*}{ Culture of activity } & Everyday behaviour & 12 & $\begin{array}{l}\text { "A culture of behaviour - our daily } \\
\text { behaviour: culturedness, } \\
\text { neatness". (13) }\end{array}$ \\
\hline & $\begin{array}{l}\text { Diversity of } \\
\text { situations }\end{array}$ & 2 & $\begin{array}{l}\text { "A culture of behaviour - the hygiene skills, } \\
\text { a culture of behaviour in different } \\
\text { situations, positive interrelationships in } \\
\text { different situations, tolerance, respect". (14) }\end{array}$ \\
\hline \multirow{3}{*}{$\begin{array}{l}\text { Culture of } \\
\text { communication }\end{array}$} & $\begin{array}{l}\text { Positive } \\
\text { interrelationships }\end{array}$ & 4 & $\begin{array}{l}\text { "A culture of behaviour - the hygiene skills, } \\
\text { a culture of behaviour in different } \\
\text { situations, positive interrelationships in } \\
\text { different situations, tolerance, respect". (14) }\end{array}$ \\
\hline & Moral values & 10 & $\begin{array}{l}<\ldots>\text { courtesy, respect for others, } \\
\text { responsibility." (6) }\end{array}$ \\
\hline & Communication & 6 & $\begin{array}{l}\text { "Courtesy, tolerance, } \\
\text { culturedness, ability to communitivity, } \\
\text { orderliness, temperance, etc." (18) }\end{array}$ \\
\hline $\begin{array}{l}\text { Culture of } \\
\text { hygiene }\end{array}$ & Hygiene skills & 6 & $\begin{array}{l}\text { "A culture of behaviour - the hygiene skills, } \\
\text { a culture of behaviour in different } \\
\text { situations, positive interrelationships in } \\
\text { different situations, tolerance, respect". (14) }\end{array}$ \\
\hline $\begin{array}{l}\text { Ecological } \\
\text { education }\end{array}$ & Nurturing nature & 4 & " $<\ldots>$ respect and love for nature". (16) \\
\hline
\end{tabular}

Apart from the culture of activity, communication, and hygiene, the teachers attributed ecological and national education to the development of a culture of behaviour. Children are exposed to nature from an early age and it is important to properly organize the interaction between the child and nature. The goal of ecological education is ecological culture reflecting the ecological position or proper relation of the 
individual to nature. Already in preschool, children are taught how to deal with nature and animals properly. The attitude of the research participants that ecological education can be attributed to the development of a culture of behaviour also proves this. The informants also highlighted the importance of national education in a culture of behaviour. The goal of national education is to educate a person who can fulfil the purpose and vocation of the nation and realize its ideal - national harmony in the name of the strength and prosperity of the homeland (Jovaiša, 2012).

Successful development of a culture of children's behaviour is determined by the teacher's ability to choose methods and apply them to the respective field. Alijošienè (2003) points out that the development of a culture of children's behaviour is a very complicated process that requires the flexible and conscious use of different methods (Alijošienè, 2003). Therefore, the questionnaire aimed to find out what educational methods and techniques teachers use to properly develop a culture of behaviour in preschool.

\begin{tabular}{|c|c|c|}
\hline Category & $\begin{array}{l}\text { The number } \\
\text { of the state }\end{array}$ & Examples of statements illustrating the category \\
\hline Playing & 8 & $\begin{array}{l}\text { " }<\ldots>\text { I teach them to use polite words when sharing } \\
\text { didactic games with friends". (3) }\end{array}$ \\
\hline $\begin{array}{l}\text { Conversation (in the } \\
\text { group, in public places) }\end{array}$ & 14 & $\begin{array}{l}\text { "conversations about polite words, greeting, farewell, } \\
\text { apologizing, how to cover when sneezing; about } \\
\text { harassment, bullying". (13) }\end{array}$ \\
\hline Educational activity & 8 & $\begin{array}{l}\text { "we discuss situations in all activities: in the group, } \\
\text { outdoors, in public places." (1) }\end{array}$ \\
\hline Example & 4 & "< <..> by personal example." (2) \\
\hline Praising & 2 & $\begin{array}{l}\text { "I encourage positive behaviour by praising, sometimes } \\
\text { rewarding." (1) }\end{array}$ \\
\hline Rewarding & 2 & $"<\ldots>$ sometimes rewarding." $(15)$ \\
\hline Relationships with others & 10 & $\begin{array}{l}\text { " }<\ldots>\text { listening to an adult, apologizing when you hurt } \\
\text { your friend, controlling emotions." (1) }\end{array}$ \\
\hline
\end{tabular}

Playing in the preschool age becomes the main motive for the activity, because "while playing, children actively learn the rules of interrelationships, norms of social behaviour, understanding the other, sympathizing, providing help, etc." (Ratkus, 1993, p. 124). Malinauskienè (2012) also states that games are the main activity of the child, which plays a significant role in his/her educational process and stimulates the child's thinking, emotionality, and need for communication. It is also confirmed by the results of the research. In the preschool teachers' opinion, with the help of games in various educational activities, children develop appropriate behavioural norms. The teachers who participated in the research use games in all educational activities.

According to the informants, the method of conversation is also important for the development of a culture of behaviour. They state that various conversations take place during education on the topics of behaviour, good and bad behaviour is discussed, situations are created, which are intended to show a good or bad deed.

The research revealed that teachers use other well-known methods in their work: example, praising, sometimes rewarding. The methods of maintaining appropriate relationships with others, pursuing common suggestions and interests are also indicated.

\section{Discussion}

The essence of a culture of behaviour is to develop a virtuous personality, responsible for his/her actions, able to make the right decisions, respect and preserve nature, national traditions, customs, communicate and cooperate, become a full member of society. It is the development of socially acceptable rules of behaviour, the development of skills of independence, communication, hygiene, love for nature, one's nation, its history and customs. All this makes up the image of a cultured person.

The development of a culture of behaviour of preschool children is important because at this age children begin to understand the diversity of human relationships and activities and the world of social functions.

A focused and purposeful education of preschool children has a huge impact on their successful development, their relationships with people - adults and peers, their self-esteem, well-being, behaviour 
and even the success of their further life. During this period, it is important for the teacher to gain the trust of the child because the main education of preschool children is direct communication with them: playing, conducting conversations, including ethical, showing a personal example, praising Modelling of the educational process influences the learners' relationships and the proper culture of behaviour in dealing with others, therefore, to develop a thrifty attitude to toys, to be able to overcome difficulties, to complete the work started, to feel grateful for care and attention, and to be friendly with peers and adults - all of these are the main directions of the educator's pedagogical work programme when working with preschool children.

The development of a culture of children's behaviour is a conscious and flexible process, during which various ways of the development of a culture of behaviour are applied: interesting activity related to games, outings, leisure time with friends; watching cinema, theatres, plays, television; traditional celebrations and entertainment; example; praising; positive comments, talking about activity and behaviour, about feelings and needs of the child's peers; rewarding and discipline.

The results of the conducted research can be applied to improve the curricula of preschool education institutions in order to find and use the most appropriate methods for developing a culture of children's behaviour. The dissemination of results is relevant not only to the scientists' community and education policy makers, but also to practitioners, i.e., educational articles, consulting sessions for heads of institutions, because it will help to answer the question of how to model the concept of the development of a culture of children's behaviour in the search for various experiences and alternatives.

The results of the research revealed that teachers mostly use traditional methods in developing a culture of children's behaviour. It is worth noting that in order to achieve good results in the development of a culture of behaviour, it is also necessary to look for non-traditional ways of education that could interest children. Although traditional methods of education are time-tested, they do not attract as much interest from children as non-traditional ones: campaigns, trips, and so on.

Conducting the research, the qualitative research strategy applied in the country's higher education institutions was followed. It helps to reveal the authentic experience of the research participants. Applying the qualitative research and the method of an open-ended written survey of teachers, there were some difficulties in getting the completed questionnaires back. This time, the research analysed the experience of teachers. Involving parents of students in the research would make it more diverse, because the influence of parents on preschool children is particularly significant.

Further studies of the topic under analysis could also include a survey of education policy makers and municipal specialists. It would be possible to refer to other research methods (focus groups, interviews), which would help to reveal what strategies in the aspect of a culture of children's behaviour are being developed and planned at the state level in the perspective of improving the education system of Lithuania.

\section{References}

Alijošienè, Z. (2003). Elgesio kultūros ugdymas [Development of a culture of behaviour]. Šiauliai: K. J. Vasiliausko įmonè. Berger, P. L., Luckmann, T. (1966). The Social Construction of Reality: A Treatise in the Sociology of Knowledge. Garden City, NY: Anchor Books.

Bitinas, B. (2004). Hodegetika. Auklëjimo teorija ir technologija [Hodegetics. Theory and technology of parenting]. Vilnius: Kronta.

Bitinas, B., Rupšienė, L., Žydžiūnaitè, V. (2008). Kokybiniu tyrimu metodologija [Qualitative Research Methodology]. Klaipèda: S. Jokužio leidykla.

Burvytè, S. (2016). Tẻvų, auginančių ikimokyklinio amžiaus vaikus, pozityviosios tėvystės suvokimas. Socialinis ugdymas [Positive Parenthood Perception of Parents Raising Pre-school Children. Social education], 3, 36-57. ISSN 1392-9569/

E-ISSN 2351-6011.

Cramm, D. (2005). Geros vaikų manieros [Good children's manner]. Vilnius: Algarvè.

Child Line Annual Activity Report (2018). Retrieved from: https://issuu.com/vaikulinija/docs/vlmetinataskaita2018-issuu

Grace, E. (2017).Vygotsky and Socio-cultural Theory. Retrieved from

http://www.kidsdevelopment.co.uk/VygotskySocioCulturalTheory.html

Jovaiša, L. (2012). Edukologija. II tomas [Educology, II volume]. Vilnius: Agora.

Jung, H. Y., Reifel, S. (2011). Promoting Children's Communication: A Kindergarten Teacher's Conception and Practice of Effective Mathematics Instruction. Journal of Research in Childhood Education, 25(2), 194-210.

https://doi.org/10.1080/02568543.2011.555496 
Kardelis, K. (2017). Mokslinių tyrimų metodologija ir metodai [Research Methodology and Methods]. Vilnius: Mokslo ir enciklopedijų leidybos fondas.

Leliūgienè, I. (2003). Socialinè pedagogika [Social pedagogy]. Kaunas: Technologija.

Lenartavičienė, L. (2011, September). Gerų darbų kultūros ugdymas [Developing a culture of good deeds]. Retrieved from: https://www.ikimokyklinis.lt/index.php/straipsniai/bendri-straipsniai/151?page=7

Lietuvos Respublikos švietimo ịstatymas [Law on Education of the Republic of Lithuania] (2011). Retrieved from: https://eseimas.lrs.lt/portal/legalAct/lt/TAD/TAIS.395105

Malinauskienè, D. (2012). I̦ vaiką orientuoti ugdymo tyrimai: socialinis-edukacinis kontekstas: mokslo darbu apžvalga [Child-centered educational research: The social-educational context: a review of scholarly work]. Šiauliai: Šiaulių universiteto leidykla.

Masiliauskienė, E., Smilgienè, J., Urbonienè, R. (2014). Vaikų elgesio kultūros ugdymas šeimoje: tèvų požiūris [Developing a culture of child behavior in the family: the parents' attitude]. Socialinis ugdymas: postmodernios visuomenès iššukiai vaiku ir jaunimo socializacijai [Social Education: Challenges of Postmodern Society to the Socialization of Children and Young People]. Vilnius: BMK.

Peterina, S. (1989). Vaiko elgesio kultūra [Child social culture]. Kaunas: Šviesa

Petrylienè, N., Smilgienė, J. (2013). Drausminimas - vienas iš ikimokyklinio amžiaus vaikų elgesio kultūros ugdymo būdu [Disciplining as One of the Methods of Development of Behaviour Culture of Preschoolers]. Jaunuju mokslininku darbai [Proceedings of Young Scientists], 1, 56-62. Retrieved from: file:///c:/users/user/downloads/6097350\%20(1).pdf

Ratkus, J. (1993). Pasaulio pažinimą - doriniam ugdymui. Dorinis ugdymas. Teorija ir praktika [Knowledge of the world for moral education. Moral education. Theory and practice]. Šiauliai: ŠPI.

Skujienè, G., Steponėnienè, A. (2007). Šeimos etika [Family Ethics]. Vilnius: Rosma.

Smilgienė J., Jonaitienė D. (2019). Vaikų elgesio kultūros ugdymo(si) būdai ir metodai Radviliškio „X“ ikimokyklinėje ugdymo isstaigoje (atvejo analizè) [Teaching/learning methods used in x preschool institution in Radviliškis aimed at developing children's social behaviour (Case analysis)]. Jaunuju mokslininku darbai [Proceedings of Young Scientists], 49 (1), 16-26. DOI: 10.21277/jmd.v49i1.212.

Žemaitis, V. (2005). Šeimos etika [Family Ethics]. Vilnius: Rosma

Žygaitienè, B. (2003). Teorinis elgesio kultūros ugdymo modelis ir jo integravimo ị technologijų pamokas galimybès. Pedagogika [The theoretic model of education of culture of behaviour and the possibilities of its integration into lessons of Technologies, Pedagogy], 68, 309-314. https://www.vdu.lt/cris/handle/20.500.12259/93890

Weiss, S.J., Goebel, P., Page, A. et al. (1999). The Impact of Cultural And Familial Context on Behavioral And Emotional Problems of Preschool Latino Children. Child Psychiatry Hum Dev 29, 287-301. doi.org/10.1023/a:1021397032359

Han, H. S. (2014). Supporting Early Childhood Teachers To Promote Children's Social Competence: Components For Best Professional Development Practices. Early Childhood Education Journal 42 (3), 171-179. doi:10.1007/s10643-013-0584-7 